\title{
DOES THE RIDER INFLUENCE THE HORSE'S MOVEMENT IN HIPPOTHERAPY?
}

\author{
Zdeněk Svoboda, Tereza Dvořáková, Miroslav Janura
}

Faculty of Physical Culture, Palacký University, Olomouc, Czech Republic

Submitted in September, 2011

BACKGROUND: In hippotherapy, in comparison to equitation, it is assumed that the rider is a passive element, only stimulated by mechanical impulses produced by the moving horse's back.

OBJECTIVE: The aim of the study was to determine the influence of the rider on the horse's movement in hippotherapy.

METHODS: Two sound thoroughbreds with a similar body shape and size (age - 19 and 14 years, withers height $1.65 \mathrm{~m}$ both, weight -548 and $500 \mathrm{~kg}$ ) participated in the study. The test group of riders consisted of twelve healthy young women (age $-23.3 \pm 2.8$, weight $-59.2 \pm 5.3$, height $-167.3 \pm 4.2$ ) without any previous horse riding experience. For each rider 36 trials in total ( 6 strides in 6 hippotherapy sessions held during the course of five weeks) were evaluated. The movement was recorded by 4 videocameras (frequency $50 \mathrm{~Hz}$ ). Spatiotemporal variables, the vertical displacement of selected points on the horse's limbs and the back and angle displacement of tarsus joint were analyzed by the APAS programme. Statistical processing was performed by the Statistica programme (one way ANOVA).

RESULTS: In our study, we didn't find any statistically significant difference $(p<0.05)$ for stride duration, stride length and a horse's walking velocity. Upon the walking of horse no. 1 with various riders, statistically significant differences $(\mathrm{p}<0.01)$ in the vertical and angle displacement of points on the hind limb and on the horse's back were found. For horse no. 2, a statistically significant influence of the rider on the movement of the horse was found only in the vertical displacement of the fore hoof.

CONCLUSIONS: In hippotherapy, basic spatiotemporal variables of a horse's natural walking aren't influenced by the rider. As for the vertical displacement of points on the limbs and the horse's back, the results are not explicit. A larger number of horses is necessary for future study. The patient and the horse in hippotherapy are to be rather considered as interactive elements than as passive and active elements.

\section{INTRODUCTION}

The physiological basis of hippotherapy is the three dimensional transmission of the horse's motion over to the patient's body (Schwesig, Neumann, Richter, Kauert, Becker, Esperer, \& Leuchte, 2009). The horse's movements affect that of the patient's, thus opening possibilities to influence the rider's pelvic and torso motor activity (Hakanson, Möller, Lindström, \& Mattsson, 2009). Hippotherapy can be characterised as the three dimensional movement of the horse's hips and pelvis as the hind legs move forward during the walk that provides a movement challenge to the client (Heine, 2003). The magnitude of movement impulses from the horse's back can be influenced by equine conformation (Matsuura, Ohta, Ueda, Nakatsuji, \& Kondo, 2008), walking speed (Dvořáková, Janura, Vyjídáková, \& Svoboda, 2004) and other factors. Matsuura et al. (2008) found that frequencies of rider oscillation for short horses were higher than those for tall horses and wide horses have a smaller vertical amplitude than narrow horses. Vertical displacement of the horse's back increases at higher walking speeds (Dvořáková et al., 2004).
Variability in a horse's back movement (L4) is influenced by the rider (it depends on whether the horse is ridden or unridden) or the fit of the saddle (fitting or non-fitting saddle). In the ridden horse the variability in velocity and acceleration in a forward direction was significantly lower than in the unridden horse (Peham, Licka, Schobesberger, \& Meschan, 2004).

In equitation the rider is the key factor that controls a horse's rhythmical movement. In hippotherapy the patient sitting on the walking horse only maintains his or her balance in a position matching his or her reached vertical level, while the movement of the horse is controlled by the leader.

The Central European concept of hippotherapy relates to neurophysiological principles of the stimulation of psychomotor development and the activation of congenital motor programs. To achieve these aims, the subject is only balanced on a walking horse in a position that corresponds to the reached vertical level of the patient. In this concept, the patient is considered to be a passive element that does not influence the horse's movement. Hippotherapy is often used for neurologically disabled subjects. Aside from pharmacological treatment (Šifta, Zahálka, \& Süssová, 2006), 
non-pharmacological treatment, mainly rehabilitation, shows some benefits for these subjects. Hippotherapy can be used for patients with various levels of physical handicap (McGee \& Reese, 2009; Schwesig et al., 2009; Lechner, Kakebeeke, Hegemann, \& Baumberger, 2007).

In some cases, it can be supposed that there is asymmetrical loading of the horse caused by the patient in, for example, cases of hemiparesis, amputation, balance disorders, etc. These factors can be considered during the horse's dressage. In hippotherapy, the horse has to resist the impulses of the patient. Despite a certain level of discomfort, the horse has to retain a relaxed back movement and clear limb mechanics.

On the basis of the above stated data, we generated a few queries. Is it possible to consider the horse to be a therapeutic device producing relatively uniform movement impulses on subjects with similar body weight and body height? Does a healthy rider influence the horse's movement in hippotherapy?

The main aim of the study was to determine the influence of the rider on the horse's movement in hippotherapy.

\section{METHODS}

\section{Observed groups}

Two thoroughbreds of a similar body shape and size (age - 19 and 14 years, withers height for both $-165 \mathrm{~cm}$, weight -548 and $500 \mathrm{~kg}$ ) participated in this study. The horses were in a good state of health, i. e. fully efficient. The group of riders consisted of twelve healthy young women (age $-23.3 \pm 2.8$ years, height $-167.3 \pm 4.2 \mathrm{~cm}$, weight $-59.2 \pm 5.3 \mathrm{~kg}$ ) without any previous horse riding experience. Six persons were observed on each horse.

\section{Experimental set up and data collection}

The experiment was carried out under over-ground conditions natural for hippotherapy. The horses were given an initial warm up (led by hand) of 15 minutes prior to the start of the experiment. Then six contrasting hemispheric markers ( $4 \mathrm{~cm}$ in diameter) were attached to each horse (Fig. 1). For each ride, 36 trials in total (6 stride cycles in the course of six hippotherapy lessons held during a period of five weeks) were evaluated.

\section{Data analysis}

The horse's movement was recorded by 4 videocameras (with a frequency of $50 \mathrm{~Hz}$ ). The APAS programme (Ariel Dynamics Inc. Trabuco Canyon, CA, USA) was used for kinematic variables processing.

Stride duration [s], stride length [m], walking velocity $\left[\mathrm{m} \cdot \mathrm{s}^{-1}\right]$, the vertical displacement of the hoof of the fore limb (fore hoof), the hoof of the hind limb (hind hoof) and the sacral tuber on the horse's back [m] and the angle displacement of the tarsus joint $\left[{ }^{\circ}\right]$ were evaluated.

Displacements were measured according to the global coordinate system. The " $x$ " axis was a vector running in the direction of the movement. The " $y$ " axis was calculated as the vector perpendicular to the $x$-axis on the horizontal plane. The " $\mathrm{z}$ " axis was calculated as a vector perpendicular to both $\mathrm{x}$ and $\mathrm{y}$-axes being positive in an upward direction.

Stride duration was found in the record of the horse's movement. Stride length was derived as the difference between the x-coordinates of the hind hoof at the beginning of two sequent stride cycles. Walking velocity was calculated as stride length divided by stride duration.

Statistical processing was performed by the Statistica programme (version 8.0, Stat-Soft, Inc., Tulsa, OK, USA). The significance of statistical differences was evaluated by the one way analysis of variance for each horse. A statistically significant level p 0.05 was established.

Fig. 1

Evaluated points and angles on the horse's body

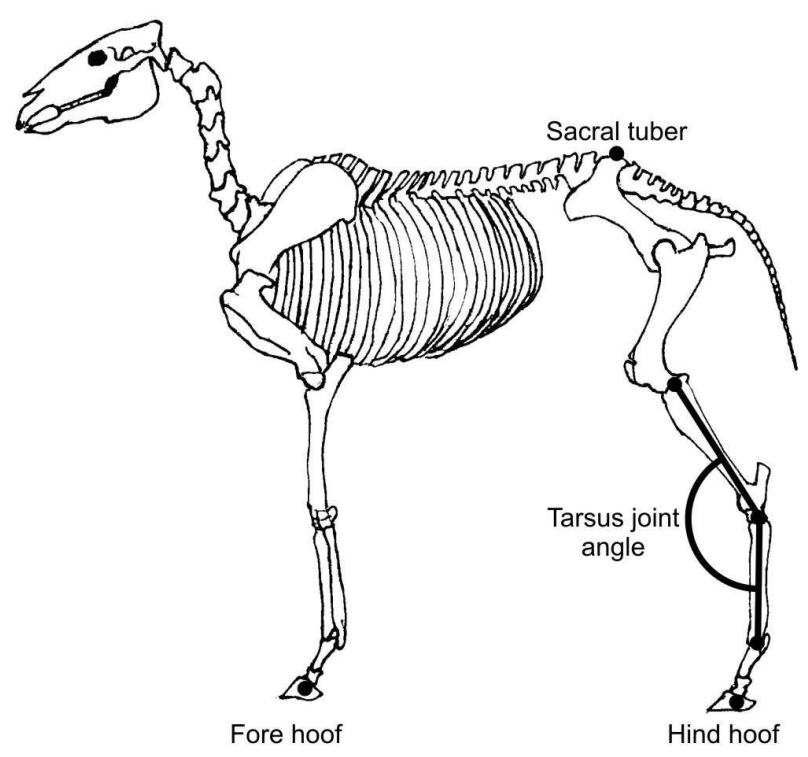

\section{RESULTS}

We didn't find any statistically significant difference $(p<0.05)$ for stride duration, stride length and a horse's walking velocity among different riders in the case of either horse (TABLE 1, TABLE 2).

For horse no. 1 a statistically significant difference ( $p<0.01$ ) was found in the vertical displacement of the hind hoof and the sacral tuber (TABLE 1). The greatest difference showed the angle displacement of the tarsus joint (Fig. 2). For horse no. 2, a statistically significant influence of the rider on the movement of the horse was found only for the fore hoof. 
TABLE 1

Values of measured variables for horse no. 1 with six different riders

\begin{tabular}{|c|c|c|c|c|c|c|c|c|}
\hline Horse 1 & Rider & 1 & 2 & 3 & 4 & 5 & 6 & $\mathbf{F}$ \\
\hline \multirow{2}{*}{$\begin{array}{l}\text { Stride duration } \\
\text { [s] }\end{array}$} & Mean & 1.20 & 1.22 & 1.22 & 1.20 & 1.22 & 1.21 & \multirow{2}{*}{0.71} \\
\hline & SD & 0.043 & 0.023 & 0.035 & 0.038 & 0.044 & 0.030 & \\
\hline \multirow{2}{*}{$\begin{array}{l}\text { Stride length } \\
\text { [m] }\end{array}$} & Mean & 1.76 & 1.78 & 1.73 & 1.74 & 1.77 & 1.75 & \multirow{2}{*}{1.20} \\
\hline & SD & 0.061 & 0.053 & 0.055 & 0.058 & 0.066 & 0.086 & \\
\hline \multirow{2}{*}{$\begin{array}{l}\text { Walking speed } \\
{\left[\mathrm{m} . \mathrm{s}^{-1}\right]}\end{array}$} & Mean & 1.47 & 1.47 & 1.42 & 1.45 & 1.46 & 1.45 & \multirow{2}{*}{0.65} \\
\hline & SD & 0.094 & 0.056 & 0.043 & 0.071 & 0.093 & 0.082 & \\
\hline \multirow{2}{*}{$\begin{array}{l}\text { Fore hoof } \\
{[\mathrm{m}]}\end{array}$} & Mean & 0.075 & 0.075 & 0.068 & 0.074 & 0.069 & 0.075 & \multirow{2}{*}{1.06} \\
\hline & SD & 0.018 & 0.022 & 0.013 & 0.019 & 0.011 & 0.019 & \\
\hline \multirow{2}{*}{$\begin{array}{l}\text { Hind hoof } \\
\text { [m] }\end{array}$} & Mean & 0.095 & 0.103 & 0.091 & 0.092 & 0.088 & 0.105 & \multirow{2}{*}{$3.59 * *$} \\
\hline & SD & 0.012 & 0.024 & 0.019 & 0.019 & 0.021 & 0.023 & \\
\hline \multirow{2}{*}{$\begin{array}{l}\text { Sacral tuber } \\
{[\mathrm{m}]}\end{array}$} & Mean & 0.056 & 0.065 & 0.064 & 0.059 & 0.060 & 0.056 & \multirow{2}{*}{$5.43^{* *}$} \\
\hline & SD & 0.008 & 0.006 & 0.010 & 0.008 & 0.009 & 0.011 & \\
\hline \multirow{2}{*}{$\begin{array}{l}\text { Tarsus Joint Angle } \\
\left({ }^{\circ}\right)\end{array}$} & Mean & 38.3 & 42.5 & 37.2 & 41.4 & 39.1 & 49.2 & \multirow{2}{*}{$6.62^{* *}$} \\
\hline & SD & 7.57 & 8.89 & 7.40 & 9.13 & 8.40 & 12.97 & \\
\hline
\end{tabular}

Legend: $\mathrm{F}$ - test score; $* *-p<0.01$

TABLE 2

Values of measured variables for horse no. 2 with six different riders

\begin{tabular}{|c|c|c|c|c|c|c|c|c|}
\hline Horse 2 & Rider & 7 & 8 & 9 & 10 & 11 & 12 & $\mathbf{F}$ \\
\hline \multirow{2}{*}{$\begin{array}{l}\text { Stride duration } \\
\text { [s] }\end{array}$} & Mean & 1.31 & 1.29 & 1.34 & 1.31 & 1.31 & 1.31 & \multirow{2}{*}{1.59} \\
\hline & SD & 0.056 & 0.048 & 0.062 & 0.058 & 0.043 & 0.056 & \\
\hline \multirow{2}{*}{$\begin{array}{l}\text { Stride length } \\
\text { [m] }\end{array}$} & Mean & 1.78 & 1.82 & 1.79 & 1.78 & 1.77 & 1.77 & \multirow{2}{*}{0.53} \\
\hline & SD & 0.111 & 0.207 & 0.104 & 0.104 & 0.099 & 0.054 & \\
\hline \multirow{2}{*}{$\begin{array}{l}\text { Walking speed } \\
{\left[\mathrm{m} . \mathrm{s}^{-1}\right]}\end{array}$} & Mean & 1.36 & 1.41 & 1.34 & 1.37 & 1.35 & 1.35 & \multirow{2}{*}{0.74} \\
\hline & SD & 0.124 & 0.164 & 0.118 & 0.131 & 0.100 & 0.078 & \\
\hline \multirow{2}{*}{$\begin{array}{l}\text { Fore hoof } \\
{[\mathrm{m}]}\end{array}$} & Mean & 0.069 & 0.064 & 0.070 & 0.061 & 0.062 & 0.069 & \multirow{2}{*}{$2.42 *$} \\
\hline & SD & 0.019 & 0.013 & 0.012 & 0.014 & 0.011 & 0.015 & \\
\hline \multirow{2}{*}{$\begin{array}{l}\text { Hind hoof } \\
{[\mathrm{m}]}\end{array}$} & Mean & 0.087 & 0.093 & 0.094 & 0.089 & 0.090 & 0.095 & \multirow{2}{*}{1.46} \\
\hline & SD & 0.017 & 0.015 & 0.011 & 0.014 & 0.011 & 0.013 & \\
\hline \multirow{2}{*}{$\begin{array}{l}\text { Sacral tuber } \\
{[\mathrm{m}]}\end{array}$} & Mean & 0.060 & 0.059 & 0.056 & 0.057 & 0.059 & 0.056 & \multirow{2}{*}{1.32} \\
\hline & SD & 0.010 & 0.008 & 0.009 & 0.006 & 0.010 & 0.005 & \\
\hline \multirow{2}{*}{$\begin{array}{l}\text { Tarsus Joint Angle } \\
\left({ }^{\circ}\right)\end{array}$} & Mean & 41.9 & 42.6 & 41.2 & 41.6 & 43.9 & 44.9 & \multirow{2}{*}{1.23} \\
\hline & SD & 7.27 & 6.85 & 7.96 & 7.36 & 7.89 & 5.38 & \\
\hline
\end{tabular}

Legend: $\mathrm{F}$ - test score; * $-\mathrm{p}<0.05$

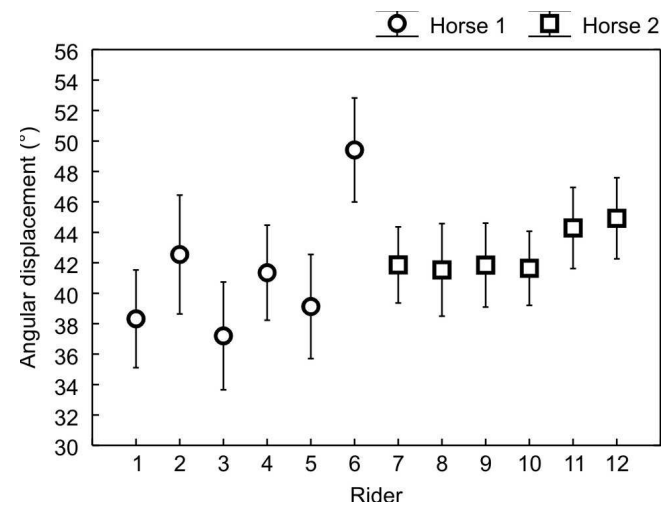

Fig. 2

Angle displacement of the tarsus joint during the stride cycle of the horses

\section{DISCUSSION}

Johnston, Holm, Erichsen, Eksell, and Drevemo (2004) demonstrated a specific significant relationship between use (dressage, jumping, eventing), gender, age, conformation and back kinematics. Horse kinematics are also influenced by a horse's breed (Cano, Vivo, Miroa, Morales, \& Galisteo, 2001). For these reasons two thoroughbreds of a similar age and conformation were chosen for our study.

Values of mean stride length (1.76 and $1.79 \mathrm{~m})$ were similar to those in the study by Faber, Johnston, van Weeren, and Barneveld (2002) (1.83 \pm 0.06 and $1.81 \pm 0.08)$. Minimal differences can be caused, among 
other reasons, due to the fact that, in our study, horses were led by leaders. Walk velocity and stride duration were different because horses in our study were measured at natural walking speed while horses in a study by Faber et al. (2002) moved on a treadmill with a constant walking speed of $1.6 \mathrm{~m} \cdot \mathrm{s}^{-1}$.

The mean angle displacement of the tarsus joint found in our study $\left(41.3^{\circ}, 42.7^{\circ}\right)$ was similar to the value $\left(43^{\circ}\right)$ presented by Hodson, Clayton, and Lanovaz (2001). Mean sacral tuber displacement was measured at $0.060 \mathrm{~m}$ and $0.058 \mathrm{~m}$. These values are similar to the value that was found by Robert, Audigie, Valette, Pourcelot, and Denoix (2001), where the vertical range of the motion of the sacral tuber was $0.063 \mathrm{~m}$ (walking speed $1.389 \mathrm{~m} . \mathrm{s}^{-1}$ ).

Differences in spatiotemporal variables influenced by the rider were not found for any of the observed horses. So the influence of a rider on complex spatiotemporal variables during hippotherapy is negligible.

With regard to kinematics variables, the results are not explicit. For one horse the differences influenced by the rider were significant for all variables in the hind limb and back. The reasons for these findings can be inter-individual differences between horses. Faber et al. (2002) mentioned that for back movements, in general, between horse variability is bigger than between stride and between day variability.

Maximal differences between the mean values of the kinematic variables of the limbs of the horses during riding of the various subjects varied from $0.009 \mathrm{~m}$ (fore hoof) to $0.017 \mathrm{~m}$ (hind hoof). The maximal difference for the angle variable was $12^{\circ}$. The maximal difference between mean values of sacral tuber displacement was 0.009 .

For back movement, an important factor is limbs movement. The horse's limbs act as springs. The stretching process stores mechanical energy, which is later released during recoil to provide propulsion (Clayton, 2004). Licka, Peham, and Zohmann (2001) indicated that back movement during the walk is driven by the motion of the limbs.

\section{CONCLUSIONS}

In hippotherapy, spatiotemporal variables of a horse's walking (stride duration, stride length, walking speed) are not influenced by the rider. With regard to the vertical displacement of points on the limbs and on the horse's back, the results are not explicit.

This study aims to answer the question of whether the rider is really a passive element who is only stimulated by the horse's back. Our answer cannot be definite. For the second horse, only one significant difference was found, whereas the kinematics of the other one (the first horse) showed significant differences for all vari- ables on the hind limb and back. So patient and horse in hippotherapy are to be considered as interactive elements rather than as passive and active elements.

There are many questions for further research. The interaction between the rider and the horse can depend on a horse's breed, horse conformation and other factors such as external conditions or the horse leader.

\section{ACKNOWLEDGEMENT}

The study has been supported by the research grant from the Ministry of Education, Youth and Sports of the Czech Republic (No. MSM 6198959221) "Physical Activity and Inactivity of the Inhabitants of the Czech Republic in the Context of Behavioral Changes".

\section{REFERENCES}

Cano, M. R., Vivo, J., Miroa, F., Morales, J. L., \& Galisteo, A. M. (2001). Kinematic characteristics of Andalusian, Arabian and Anglo-Arabian horses: A comparative study. Res. Vet. Sci., 71(2), 147-153.

Clayton, H. M. (2004) The dynamic horse a biomechanical guide to equine movement and performance. Mason: Sport Horse Publications.

Dvořáková, T., Janura, M., Vyjídáková, K., \& Svoboda, Z. (2004). Sledování pohybu hřbetu koně a jeho změny v závislosti na rychlosti kroku. Rehabilitácia, 41(2), 111-114.

Faber, M., Johnston, C., van Weeren, P. R., \& Barneveld, A. (2002). Repeatability of back kinematics in horses during treadmill locomotion. Equine Vet. J., 34(3), 235-241.

Hakanson, M., Möller, M., Lindström, I., \& Mattsson, B. (2009). The horse as the healer: A study of riding in patients with back pain. J. Bodyw. Mov. Ther., 13(1), 43-52.

Heine, B. (2003). When is therapeutic riding hippotherapy? In B. T. Engel (Ed.), Therapeutic riding II: Strategies for rehabilitation (3rd ed.) (pp. 5-10). Durango: Barbara Engel Therapy Services.

Hodson, E., Clayton, H. M., \& Lanovaz, J. L. (2001). The hind limb in walking horses: 1 . Kinematics and ground reaction forces. Equine Vet. J., 33(1), 38-43.

Johnston, C., Holm, K. R., Erichsen, C., Eksell, P., \& Drevemo, S. (2004). Kinematic evaluation of the back in fully functioning riding horses. Equine Vet. J., 36(6), 495-498.

Lechner, H. E., Kakebeeke, T. H., Hegemann, D., $\&$ Baumberger, M. (2007). The effect of hippotherapy on spasticity and on mental well being of persons with spinal cord injury. Arch. Phys. Med. Rehabil., 88(10), 1241-1248 
Licka, T. F., Peham, C., \& Zohmann, E. (2001). Treadmill study of the range of back movement at the walk in horses without back pain. Am. J. Vet. Res., 62(7), 1173-1179.

Matsuura, A., Ohta, E., Ueda, K., Nakatsuji, H., \& Kondo, S. (2008). Influence of equine conformation on rider oscillation and evaluation of horses for therapeutic riding. J. Equine Sci., 19(1), 9-18.

McGee, M. C., \& Reese, N. B. (2009). Immediate effects of a hippotherapy session on gait parameters in children with spastic cerebral palsy. Pediatr. Phys. Ther., 21(2), 212-218.

Peham, C., Licka, T., Schobesberger, H., \& Meschan, E. (2004). Influence of the rider on the variability of the equine gait. Hum. Mov. Sci., 23(5), 663-671.

Robert, C., Audigie, F., Valette, J. P., Pourcelot, P., \& Denoix, J. M. (2001). Effect of treadmill speed on the mechanics of the back in the trotting saddlehorse. Equine Vet. J. Suppl., 33, 154-159.

Schwesig, R., Neumann, S., Richter, D., Kauert, R., Becker, S., Esperer, H. D., \& Leuchte, S. (2009). Impact of therapeutic riding on gait and posture regulation. Sportverlet Sportsc, 23(2), 84-94.

Šifta, P., Zahálka, F., \& Sussová, J. (2006). Longitudional observation of walking stereotype and its changes in patiens suffering from stroke or brain injury. Isokinet Exerc. Sci., 14(2), 130-131.

\section{OVLIVŇUJE JEZDEC POHYB KONĚ V HIPOTERAPII?}

(Souhrn anglického textu)

VÝCHODISKA: V hipoterapii je, na rozdíl od jezdectví, jezdec považován za pasivní prvek, který je stimulován impulsy, které vycházejí z pohybujícího se hřbetu koně.

CÍLE: Cílem studie bylo zjistit, zda jezdec ovlivňuje pohyb koně v hipoterapii.

METODIKA: Do studie byli zařazeni dva angličtí plnokrevníci podobné tělesné konstituce (věk - 19 a 14 let, výška v kohoutku - oba 1,65 m, hmotnost - 548 a 500 kg). Skupinu jezdců tvořilo dvanáct zdravých mladých žen (věk $-23,3 \pm 2,8$, hmotnost $-59,2 \pm 5,3$, výška $167,3 \pm 4,2)$. Celkově bylo analyzováno 36 krokových cyklů koně u každého jezdce. Koně se pohybovali v kroku přirozeným tempem. Pohyb byl zaznamenán s pomocí 4 videokamer (frekvence $50 \mathrm{~Hz}$ ). Pro zpracování kinematických dat byl využit program APAS. Pro hodnocení byly vybrány časově-prostorové parametry, vertikální rozsah pohybu vybraných bodů na končetinách a hřbetu koně a rozsah úhlu $\mathrm{v}$ tarsu. Statistické zpracování bylo provedeno pomocí programu Statistica (jednofaktorová analýza rozptylu).

VÝSLEDKY: V naši studii jezdec neovlivnil trvání krokového cyklu, délku ani rychlost kroku. U koně A jsme nalezli významné rozdíly při jízdě s různými jezdci ve velikosti pohybu na zadní končetině a hřbetu. U koně $\mathrm{B}$ byl nalezen významný rozdíl při jízdě s různými jezdci pouze u rozsahu pohybu na předním kopytě ve vertikálním směru.

ZÁVĚRY: V hipoterapii základní časově-prostorové parametry koně $\mathrm{v}$ kroku při přirozené rychlosti pohybu nejsou ovlivněny jezdcem. Co se týče rozsahu pohybů ve vertikálním směru na končetinách a hřbetu koně, výsledky nejsou jednoznačné. Pro další výzkum je nezbytný větši počet koní. Pacienta a koně v hipoterapii bychom měli vnímat spiše jako dva prvky, které se vzájemně ovlivňují, než jako pasivní a aktivní prvek.

Klíčová slova: kůñ, terapeutické ježdění, kinematika, pacient, rozsah pohybu.

\section{Mgr. Zdeněk Svoboda, Ph.D.}

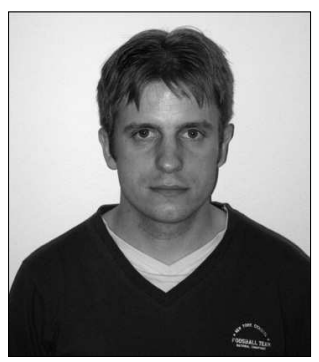

Palacký University, Olomouc Faculty of Physical Culture tř. Míru 115 77111 Olomouc Czech Republic

Education and previous work experience 2003-2007 - Ph.D. study program at the Faculty of Physical Culture, Palacký University, Olomouc.

First-line publication

Janura, M., \& Svoboda, Z. (2008). Dynamic pressure measurements in below knee prosthetics. In K. D’Août, K. Lescrenier, B. Van Gheluwe, \& D. De Clercq (Eds.), Advances in plantar pressure measurements in clinical and scientific research (pp. 171-190). Maastricht: Shaker Publishing BV.

Janura, M., Dvořáková, T., Peham, C., Svoboda, Z., \& Elfmark, M. (2010). The influence of walking speed on equine back motion in relation to hippotherapy. Wien Tierärztl Mschr, 97(3, 4), 87-91.

Svoboda, Z., Janura, M., Cabell, L., \& Elfmark, M. (2011). Kinematic analysis of the flight phase of the Nordic combined and ski jump on a large hill (HS $134 \mathrm{~m}$ ) during the 2009 Nordic World Ski Championships. Acta of Bioeng. Biomech., 13(1), 19-25.

Svoboda, Z., Janura, M., Dvořáková, T., \& Živný, B. (2011). Možnosti využití hipoterapie v klinické praxi 1. Rehabilitácia, 48(4), 214-221.

Svoboda, Z., Janura, M., Dvořáková, T., \& Živný, B. (2011). Možnosti využití hipoterapie v klinické praxi 2. Rehabilitácia, 48(4), 224-229.

Vařeková, R., Vařeka, I., Janura, M., Svoboda, Z., \& Elfmark, M. (2011). Evaluation of postural asymmetry and gross joint mobility in elite female volleyball athletes. J. Human Kinet., 27(1), 5-13. 